\title{
Bioengineered human skeletal muscle capable of functional regeneration
}

\author{
J. W. Fleming (D, A. J. Capel, R. P. Rimington, P. Wheeler, A. N. Leonard, N. C. Bishop, O. G. Davies and M. P. Lewis
}

\begin{abstract}
Background: Skeletal muscle (SkM) regenerates following injury, replacing damaged tissue with high fidelity. However, in serious injuries, non-regenerative defects leave patients with loss of function, increased re-injury risk and often chronic pain. Progress in treating these non-regenerative defects has been slow, with advances only occurring where a comprehensive understanding of regeneration has been gained. Tissue engineering has allowed the development of bioengineered models of SkM which regenerate following injury to support research in regenerative physiology. To date, however, no studies have utilised human myogenic precursor cells (hMPCs) to closely mimic functional human regenerative physiology.

Results: Here we address some of the difficulties associated with cell number and hMPC mitogenicity using magnetic association cell sorting (MACS), for the marker CD56, and media supplementation with fibroblast growth factor 2 (FGF-2) and B-27 supplement. Cell sorting allowed extended expansion of myogenic cells and supplementation was shown to improve myogenesis within engineered tissues and force generation at maturity. In addition, these engineered human SkM regenerated following barium chloride $\left(\mathrm{BaCl}_{2}\right)$ injury. Following injury, reductions in function (87.5\%) and myotube number (33.3\%) were observed, followed by a proliferative phase with increased MyoD+ cells and a subsequent recovery of function and myotube number. An expansion of the Pax7+ cell population was observed across recovery suggesting an ability to generate Pax7+ cells within the tissue, similar to the self-renewal of satellite cells seen in vivo.

Conclusions: This work outlines an engineered human SkM capable of functional regeneration following injury, built upon an open source system adding to the pre-clinical testing toolbox to improve the understanding of basic regenerative physiology.
\end{abstract}

Keywords: Skeletal muscle, Regeneration, Tissue engineering, Satellite cell

\section{Background}

Skeletal muscle possesses an innate and robust capacity to regenerate following injury, with most injuries regenerating the tissue to a state indistinguishable from that prior to injury [1]. This regenerative capacity in vivo relies upon the presence of a resident stem cell population, satellite cells (SCs), which reside between the plasma membrane (sarcolemma) of muscle fibres and the encasing basement membrane [2-4]. SCs are characterised by

* Correspondence: m.p.lewis@lboro.ac.uk

School of Sports, Exercise and Health Sciences, Loughborough University, Loughborough LE11 3TU, UK the unique position they occupy within the tissue, but also the expression of the stem cell transcription factor Pax7 [5]. Following injury SCs are activated and proliferate readily [6], producing committed myogenic precursor cells (MPCs) marked by the presence of MyoD expression [7, 8]. MPCs then fuse together and with damaged muscle fibres, regenerating myofibres lost through injury [9-11]. In addition to a myogenic lineage, non-myogenic stem cells (fibro/adipogenic progenitors (FAPs)) and immune cells support regeneration by modifying the extracellular matrix and coordinating repair and regeneration [12-14]. The interactions between

C The Author(s). 2020 Open Access This article is licensed under a Creative Commons Attribution 4.0 International License, which permits use, sharing, adaptation, distribution and reproduction in any medium or format, as long as you give appropriate credit to the original author(s) and the source, provide a link to the Creative Commons licence, and indicate if changes were made. The images or other third party material in this article are included in the article's Creative Commons licence, unless indicated otherwise in a credit line to the material. If material is not included in the article's Creative Commons licence and your intended use is not permitted by statutory regulation or exceeds the permitted use, you will need to obtain permission directly from the copyright holder. To view a copy of this licence, visit http://creativecommons.org/licenses/by/4.0/ The Creative Commons Public Domain Dedication waiver (http://creativecommons.org/publicdomain/zero/1.0/) applies to the data made available in this article, unless otherwise stated in a credit line to the data. 
these additional cell types and MPCs have been shown to be vital in the regenerative process [15-17].

In severe muscle traumas such as volumetric muscle loss (VML), surgical trauma or partial muscles tears, the regenerative capacity of skeletal muscle can be overcome, leading to non-regenerative defects such as fibrosis [18-21], interstitial adipose accumulation [13, 22, 23] and heterotopic bone formation [24, 25]. In these circumstances, individuals are left with complications such as reduced function, increased chance of reinjury and debilitating pain [26-28]. In animal models of severe traumas, there has been limited success in manipulating the regenerative process to promote muscle regeneration and reduce non-regenerative defects. Although, where clear biochemical rationale exists, for example limiting the expansion of specific cell populations with small molecules, progress has been made [29-31]. This limited success may be attributed to the lack of easily manipulated, medium-throughput models of injury and regeneration, thus limiting understanding of the fundamental biology of muscle injury and regeneration/repair.

Due to the complex cell-cell interactions and threedimensional (3D) environment necessary to accurately mimic skeletal muscle regeneration, models of muscle injury to date have been predominantly based around laboratory animals. However, animal models face limitations with low experimental throughput, complex genetic manipulations, complex pharmacological manipulation (compared to cell cultures) and ethical considerations, in addition to inherent biological variation from humans, and therefore there is a clear requirement to develop accurate and robust ex vivo models of pathophysiology [32, 33]. Advances in tissue engineering have made it possible to create engineered skeletal muscle to understand complex physiological phenomenon. Engineered skeletal muscles from cell lines [34, 35], primary laboratory animal MPCs [36-38], pluripotent stem cell (PSC) derived myocytes [39-41] and primary human MPCs [42-45] have been demonstrated, but relatively few of these engineered skeletal muscles have been shown to possess a regenerative capacity following injury [46-49].

The regenerative processes of some engineered muscle models have shown clear correlations to that of in vivo muscle, and so the utilisation of these engineered tissues in studies of regeneration is a clear opportunity to increase our understanding of skeletal muscle regenerative physiology $[46,49,50]$. Previous engineered models of regeneration have used the snake venom cardiotoxin (CTX) to induce a chemical muscle injury. CTX is widely used in animal models to produce a specific cellular model of muscle injury and has been shown to be effective in engineered tissues $[49,50]$. The model presented here takes a similar approach utilising Barium chloride $\left(\mathrm{BaCl}_{2}\right)$, which is also widely used in laboratory animals as a specific myotoxin and produces a comparable injury type [51]. $\mathrm{BaCl}_{2}$ was chosen as an injurious stimulus due to previous in vivo publications, its high water solubility and ready availability with low regulatory restrictions, allowing easy and reproducible in vitro application [20,51]. In addition, the mechanism of injury following $\mathrm{BaCl}_{2}$ treatment is a simple cellular injury specifically removing myotubes without reducing mononuclear cell number. Although chemical insults do not mimic all of the damage, specifically extracellular matrix destruction caused by mechanical injuries, usually seen in vivo these insults produce a specific and reproducible injury phenotype to ensure accurate model development [46].

To ensure that data produced by these engineered models is as relevant as possible and that these models are exploited to their full potential, engineered muscles utilising primary human cells, with a regenerative capacity mimicking that of in vivo muscle, should be developed. To account for the heterogeneity of cells found within native muscle, primary tissue-derived MPCs and not human iPSCs present the most biomimetic option for creating a representative model of human skeletal muscle regeneration.

Here we present a robust, high-content protocol to generate functional engineered human skeletal muscles from primary human MPCs. Utilising cell population sorting and media optimisation, we present human engineered skeletal muscles which regenerate function and morphology completely following injury. These engineered muscles in addition to supporting regeneration also contain a self-renewing stem cell niche, presenting an opportunity to accurately study the biology of human skeletal muscle regeneration ex vivo.

\section{Results \\ Remixing CD56+ and CD56- cell populations produce robust tissue engineered muscles}

The sorting of non-myogenic and myogenic populations from human explant cultures allows extended culture periods within the myogenic populations without a significant loss of desmin positivity, a marker of myogenic potential (Additional file 1: Fig. S1a/b). However, the use of only myogenic cells in collagen/Matrigel ${ }^{\circ}$ hydrogels produces engineered muscles of highly variable quality due to the apparent inability of these cells to reproducibly deform the hydrogel matrix (Additional file 1: Fig. $\mathrm{S} 1 \mathrm{c} / \mathrm{d}$ ). However, due to the high proportion of myogenic cells in the CD56+ fraction (referred hereafter to as $\mathrm{CD} 56+)$ constructs these engineered muscles, when successful, produce significantly more myotubes than unsorted equivalents (Additional file 1: Fig. S1 e-i). 
The CD56- population contained predominantly TE7positive cells, most likely to be interstitial fibroblasts (70.9 $\pm 28.7 \%$, Additional file 1: Fig. S2), with a small percentage of myogenic cells (desmin positive; $5.5 \pm$ 6.1\%, Additional file 1: Fig. S2). The remainder of cells were identified utilising flow cytometry showing the presence of other muscle associated cell types, such as PDGFR $\alpha+$ (Fibro-Adipogenic Progenitors; FAPs; $1.16 \pm$ $1.24 \%), \mathrm{CD} 90+$ (mesenchymal stem cell marker; $13.9 \pm$ $13.0 \%), \mathrm{CD} 45+$ (immune cell lineage; $2.03 \pm 1.66 \%$ ) and CD31+ (endothelial cell marker; $5.60 \pm 4.86 \%$ ). All of these cell types were present as relatively small percentages of the population when compared to the TE7 population (Additional file 1: Fig. S2).

To exploit the high myogenic potential of CD56+ cells, a dose remixing experiment was undertaken to identify the lowest proportion of CD56- cells required to reproducibly deform collagen/Matrigel ${ }^{\circledR}$ constructs. The deformation of these constructs is a key feature of their development, generating tension to align developing myotubes. The CD56- cell fraction was therefore remixed with the $\mathrm{CD} 56+$ fraction at various ratios $(10 \%$ 9:1 CD56+:CD56-, 30\% 7:3 CD56+:CD56- and 50\% 1:1 CD56+:CD56-) and hydrogel deformation and morphological appearance of the tissue examined. All ratios produced engineered muscles which deformed robustly, without any significant difference between conditions (Fig. 1a/b). Clear trends in morphological appearance were present across conditions with 10\% CD56- constructs displaying the highest number of myotubes per square $\mathrm{mm}$ and the largest percentage of constructs occupied by myotubes (Fig. 1d, e, and g). A small decrease between 10 and 30\% CD56- and a much larger step between 30 and 50\% CD56- engineered muscles was observed indicating that increasing the CD56- fraction reduced myogenic potential (Fig. 1d, f). As the proportion of CD56- cells increased, these measures of myotube formation were reduced, although this trend was not significant. Myotube cross-sectional areas (CSA) remained unaffected by the proportion of CD56- cell included in constructs (Fig. 1f). As 10\% CD56- remixing produced robust deformation and allowed the maximum inclusion of the CD56+ myogenic fraction, this remixing ratio was carried forward for all future experiments.

\section{Media supplementation increases morphological and functional markers of muscle maturity}

Engineered muscles (CD56-:CD56+, 10:90) were supplemented either in the growth phase (days 0-4) or the differentiation phase (days 4-14) of culture with $2 \%$ B27 supplement. Supplementation with B-27 increased nuclei number approximately 2-fold irrespective of the phase in which it was added ( $p=0.001, p=0.004$, Fig. 2e). However, only supplementation in the differentiation phase of culture lead to increases in total myosin heavy chain $(\mathrm{MyHC})$ coverage, myotube number and myotube CSA $(p<0.001, p<0.001, p=0.004$, Fig. $2 \mathrm{a}-\mathrm{d})$. No significant changes in force generation were observed in any B-27 supplementation conditions; however, supplementation in the differentiation phase of development did lead to a mean increase in tetanic force of 8 -fold, although this response was highly variable between repeats.

Supplementation of GM with FGF2 at $5 \mathrm{ng} / \mathrm{mL}$ followed by 10 days in B-27 supplemented DM (+FGF, Fig. 2) was compared to unsupplemented GM followed by B-27 supplemented DM (-FGF, Fig. 2). FGF2 supplementation did not change any morphological measure significantly (Fig. 2i, k-n). However, FGF2 addition did increase force generation significantly for both tetanus (1.9-fold, $p=0.017$ ) and twitch (1.74-fold, $p=0.044)$. This data allowed the selection of FGF2 supplemented GM and B-27 supplemented DM as suitable medias for the culture of $10 \%$ CD56- engineered human skeletal muscles.

\section{Human engineered muscles contain multinucleated myotubes, Pax7+ nuclei and laminin organisation}

To identify how similar engineered skeletal muscle was in its matrix and cellular organisation to somatic muscle, features of in vivo muscle morphology were examined. Longitudinal staining for $\mathrm{MyHC}$ confirmed that structures positive for $\mathrm{MyHC}$ were multinucleated myotubes (Fig. 3a). Laminin staining of cross-sections showed clear and distinct concentrations of laminin staining surrounding virtually all myotubes within engineered muscles, closely reminiscent of the basement membrane organisation of in vivo muscle (Fig. 3b/c). However, another basement membrane component and component of Matrigel $^{\oplus}$, collagen IV, did not show a similar organisation, suggesting this enrichment is specific for laminin and not a general compression of the matrix (Additional file 1: Fig. S3). Longitudinal analysis showed the presence of Pax7+ nuclei, with a small proportion of these associated with a laminin rich area of matrix or the plasma membrane of myotubes (Fig. 3b).

\section{Engineered skeletal muscles are capable of functional and} morphological regeneration following injury

To examine the regenerative capacity, and so the function of the Pax7 niche, engineered muscles were exposed to an injurious stimulus in the form of $\mathrm{BaCl}_{2}$ exposure. Injury caused an initial reduction of $27.5 \%$ in $\mathrm{MyHC}$ positive coverage $(p=0.006)$ and this reduction in coverage became more pronounced up to 4 days post injury $(54.7 \%, p<0.001$, Fig. 4a, d). This reduction was caused predominantly by a loss of myotubes (myotubes per square $\mathrm{mm}$ ), from $972 \mathrm{~mm}^{-2}$ pre-injury to $789 \mathrm{~mm}^{-2}$ 


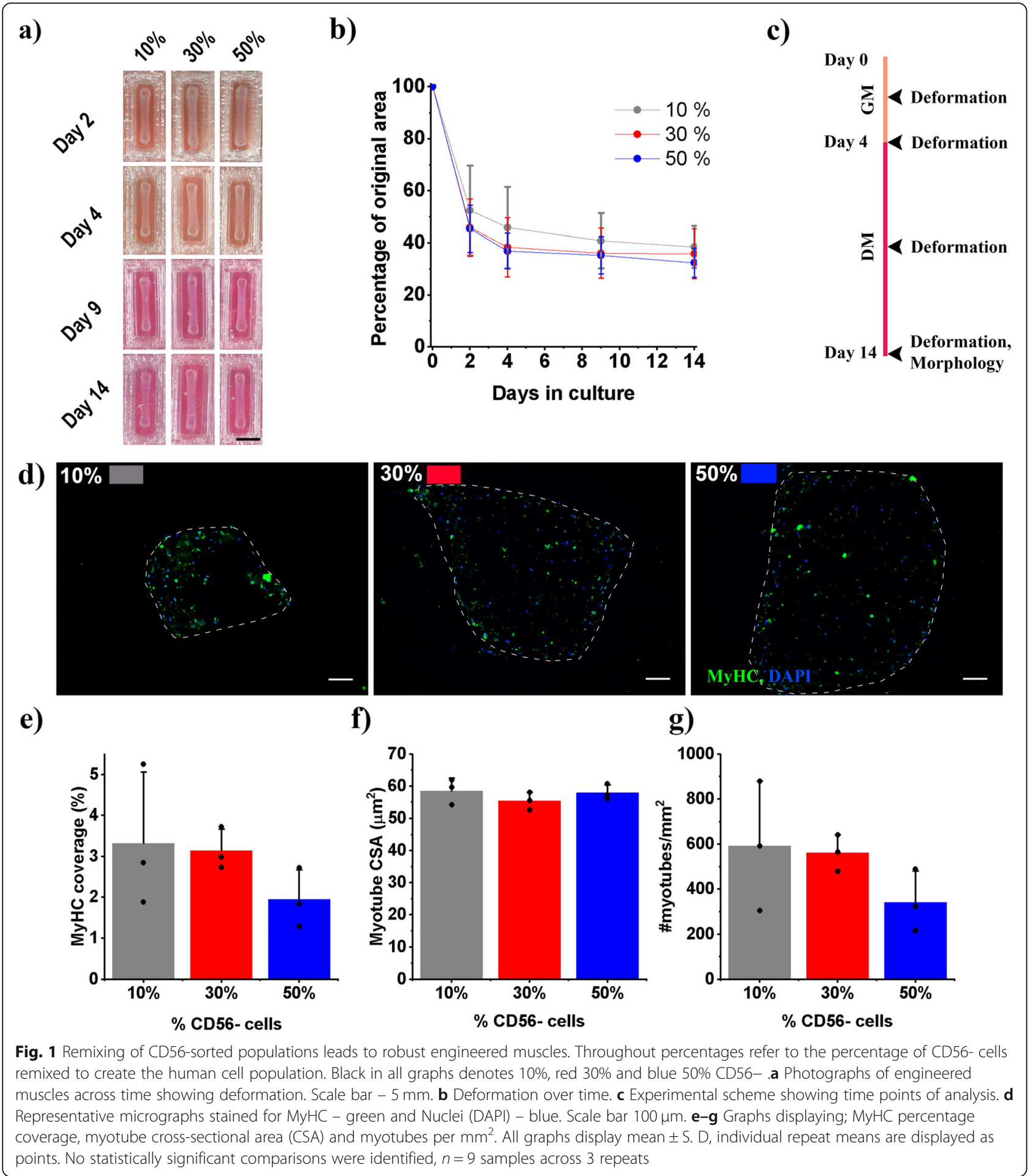

immediately post injury ( $p=0.005$, Fig. $4 \mathrm{a}, \mathrm{d})$ further reducing to $638 \mathrm{~mm}^{-2}(p=0.001) 4$ days post injury. This reduction was also accompanied by moderate atrophy of myotubes, with CSA reducing $9 \%$ following injury, although not significantly. This atrophy increased to a maximum of $29 \%\left(38.9 \mu \mathrm{m}^{2}, p<0.001\right)$ at 4 days post injury. Across all measures of myotube size and density, the largest reduction was seen between control and immediately post injury ( $6 \mathrm{~h} \mathrm{BaCl}_{2}$ incubation); however, these measures continued to decline across the first 4 days of regeneration. At 9 days post injury, $\mathrm{MyHC}$ coverage had recovered to $85 \%$ of uninjured levels and was no 
a)

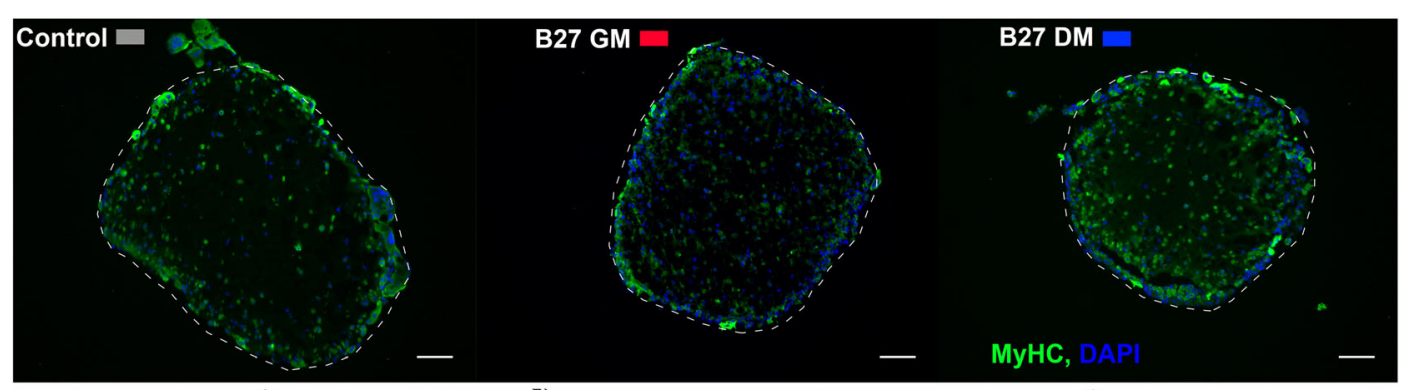

b)

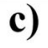

d)

e)

f)
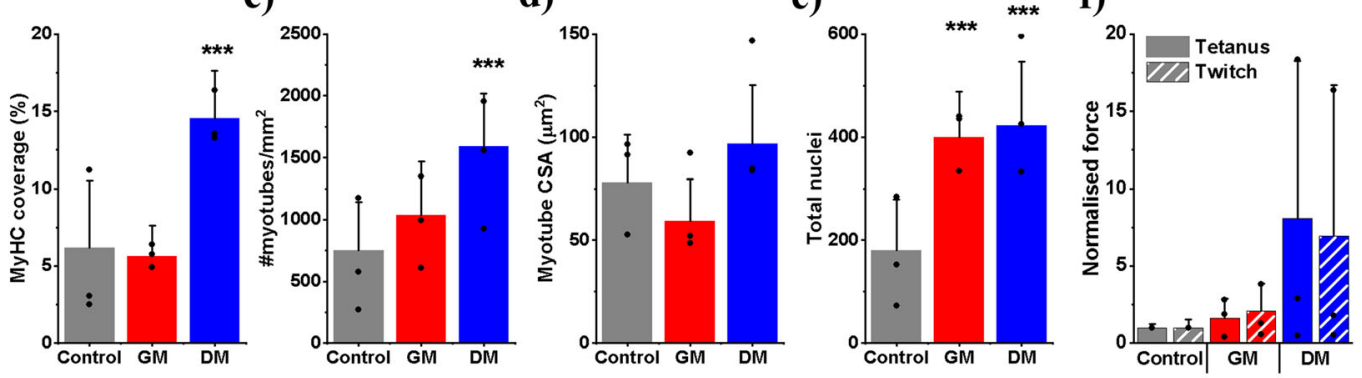

g)

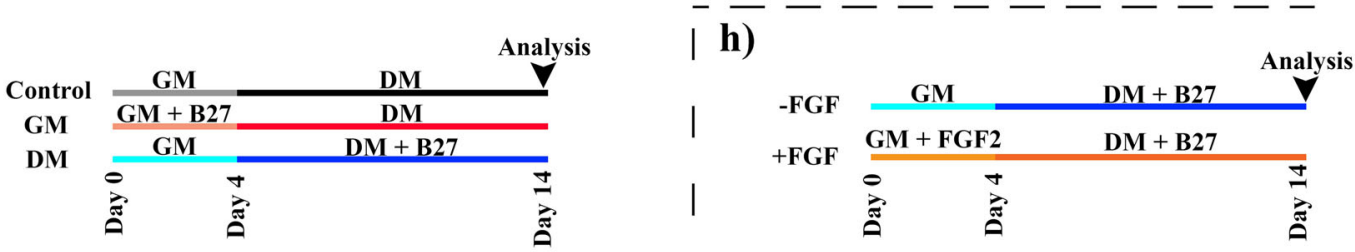

i)

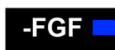

+FGF

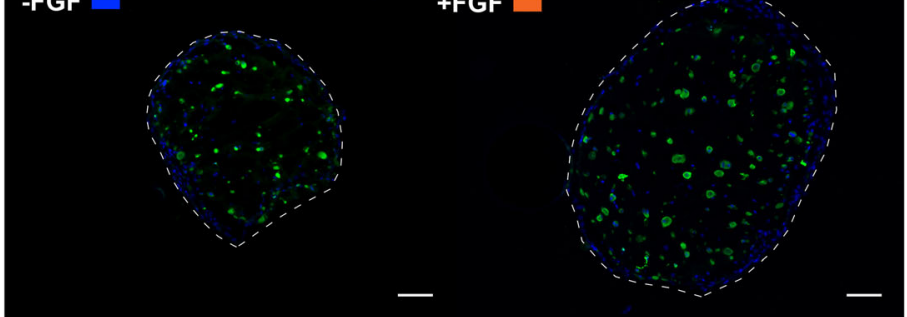

k)

l)

m)
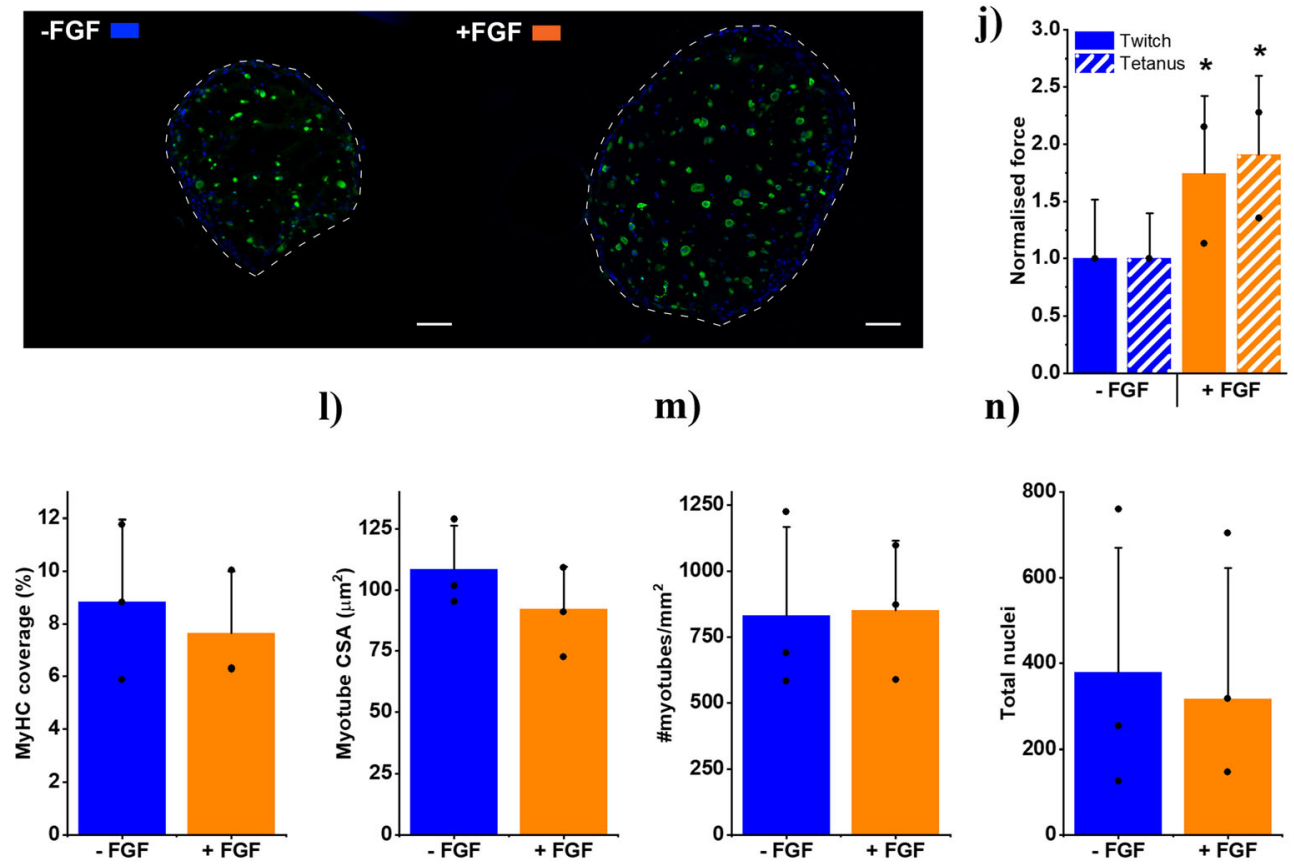

Fig. 2 (See legend on next page.) 
(See figure on previous page.)

Fig. 2 Media supplementation of remixed engineered muscles increases morphological maturity and increases functional capacity. a Representative micrographs stained for myosin heavy chain (MyHC) - green and Nuclei (DAPI) - blue. Scale bar 100 m. b-f Graphs displaying; percentage $\mathrm{MyHC}$ coverage, myotubes per $\mathrm{mm}^{2}$, myotube cross-sectional area (CSA), nuclei per section and normalised force (normalised to control), respectively. Mean tetanus force at control $45.9 \mu \mathrm{N}, 0.96 \mathrm{kPa}$; twitch force $22.7 \mu \mathrm{N}, 0.048 \mathrm{kPa}$. All graphs display mean $\pm \mathrm{S}$. D. g, $\mathbf{h}$ Experimental schemes showing conditions coloured similarly to graphs. Scheme $(\mathbf{g})$ applies to $\mathbf{a}-\mathbf{f}$ whilst scheme $(\mathbf{h})$ applies to $\mathbf{i}-\mathbf{n}$. $\mathbf{i}$ Representative micrographs stained for myosin heavy chain (MyHC) - green and Nuclei (DAPI) - blue. Scale bar $100 \mu \mathrm{m}$. $\mathbf{j}$ Normalised force (normalised to -FGF condition) mean tetanic force for -FGF condition $14.3 \mu \mathrm{N}, 0.10 \mathrm{kPa}$; twitch $6.2 \mu \mathrm{N}, 0.35 \mathrm{kPa}$. k-n Graphs displaying; Percentage MyHC coverage, myotubes per $\mathrm{mm}^{2}$, myotube cross-sectional area (CSA), nuclei per section respectively. All graphs display mean $\pm \mathrm{S}$. $\mathrm{D}$, individual repeat means are displayed as dots. Statistical significance from control $(\mathbf{a}-\mathbf{f})$ and $-\mathrm{FGF}(\mathbf{i}-\mathbf{n})$ is denoted as ${ }^{*} p \leq 0.05,{ }^{* * *} p \leq 0.001, n=9$ samples across 3 repeats

longer significantly reduced. In addition, myotubes per square $\mathrm{mm}$ had returned to $94 \%$ of uninjured controls, suggesting that myotube CSA was still depressed. Indeed, myotube CSA at day 9 post injury was significantly reduced, with an average CSA of $115 \mu \mathrm{m}^{2}$ compared to $133 \mu \mathrm{m}^{2}$ at control $(p=0.05$, Fig. $4 \mathrm{a}, \mathrm{d})$. Following the full 14 days of regeneration, all measures of myotube density and size had returned to control levels showing complete morphological regeneration of the tissue.

With morphological change, an accompanying reduction in functional output is expected. Immediately following injury, both tetanic and twitch force were reduced by an average of $62 \%$ compared to control $(p=$ $0.003, p=0.024$, Fig. 4c). Both measures of function remained significantly depressed at 2 days and 4 days post injury when compared to control. At day 9 post injury, both twitch and tetanic force were recovered to control levels and remained comparable to control at the end of regeneration at 14 days post injury (Fig. 4c).

\section{Dynamics of myogenic and non-myogenic cell populations during regeneration}

Nuclei per square $\mathrm{mm}$ was recorded to ensure that engineered muscles remained viable throughout recovery, and no significant variation in this measure was observed (Fig. 5c). However, an increase of $15 \%$ was observed 2 days post injury $(p>0.05)$, although this was resolved by 4 days post injury. To examine if different populations of cells within the overall population were expanding in relation to nuclear markers of the myogenic lineage, Pax7 and MyoD were stained for and expressed as a percentage of total nuclei. MyoD, which marks proliferative myoblasts committed to the myogenic lineage, showed no change immediately following injury. However, a significant increase from $26.4 \%$ at control to $38.6 \%$ was observed after 2 days of regeneration ( $p=0.005$, Fig. 5a). This expanded MyoD population was completely collapsed following a further 2 days, at 4 days post injury, with the percentage of MyoDpositive nuclei returning to $26.0 \%$. Through the remainder of regeneration, the percentage of MyoD-positive nuclei remained comparable to control. Pax7 a marker of satellite cells in vivo was found to be initially rare, making up only $0.42 \%$ of total nuclei at control, and no significant changes in Pax7-positive nuclei percentage was observed in the first 4 days following injury. However, following 9 days of regeneration Pax7+ nuclei comprised $2.4 \%$ of total nuclei a significant increase $(p=$
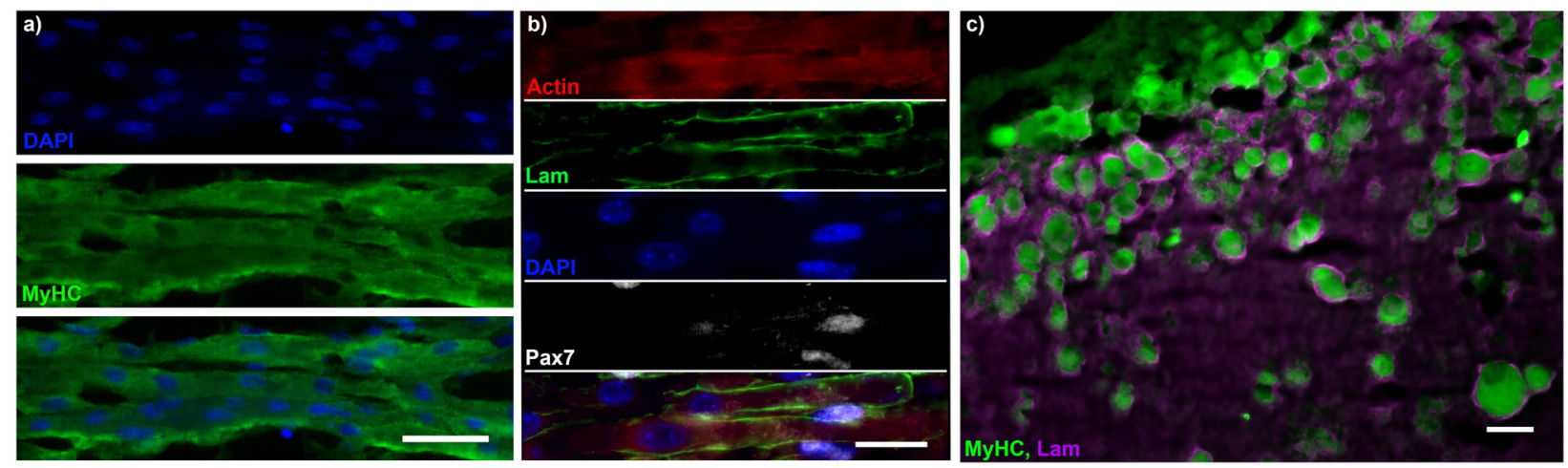

Fig. 3 Human engineered muscles display laminin organisation and Pax7+ nuclei. a Micrograph of longitudinal cryosection of engineered muscle. Stained for nuclei (DAPI, blue) and myotubes (MyHC, green). b Micrograph of longitudinal cryosection of engineered muscle. Stained for Actin (red), Laminin (green), DNA (DAPI, blue) and Pax7 (white). c Cross-section of engineered muscle imaged on the extreme periphery of the section. MyhC (green) and Laminin (magenta). All scale bars represent $25 \mu \mathrm{m}$ 


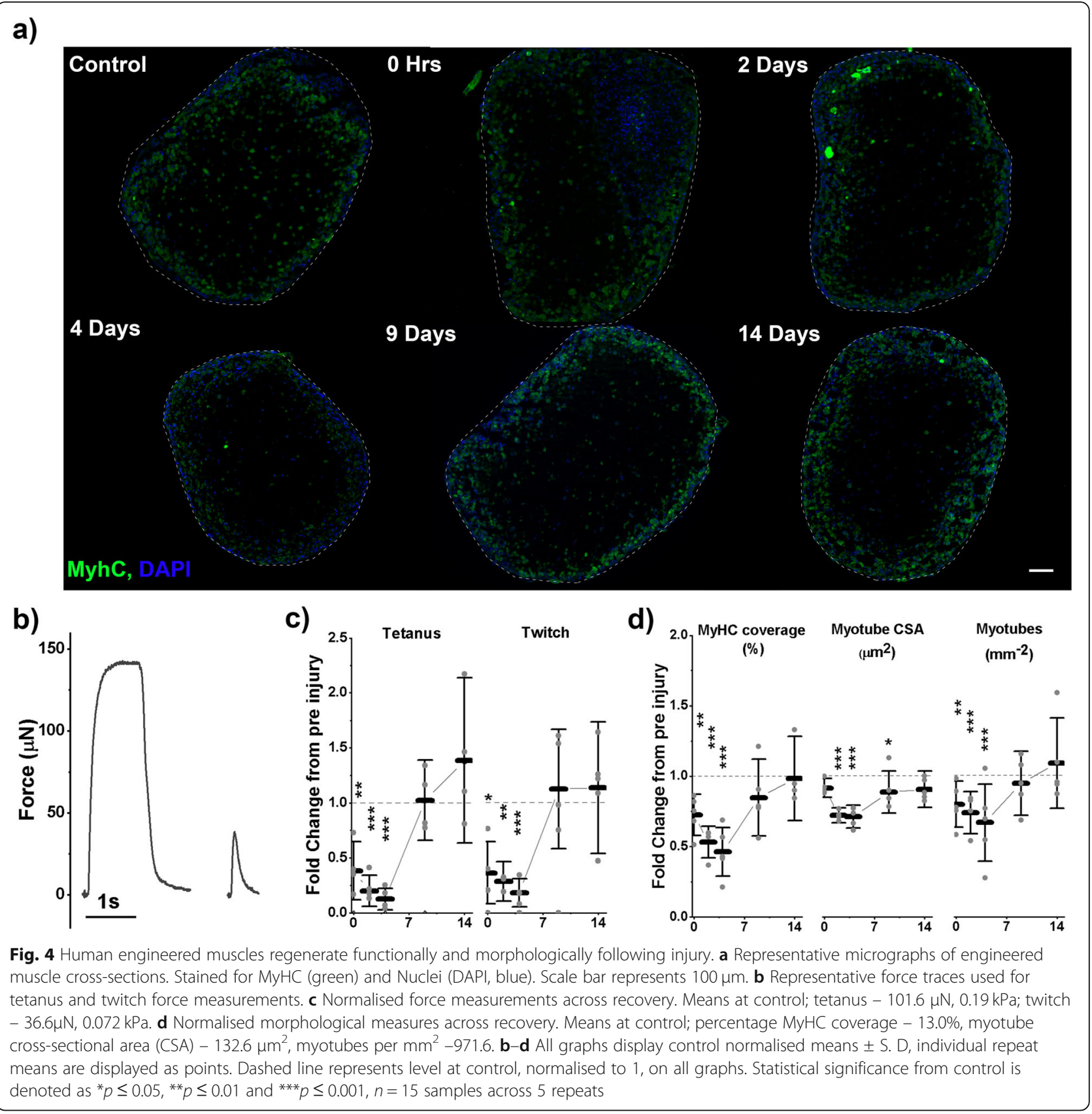

0.002 , Fig. 5b) which persisted until 14 days post injury where Pax7-positive nuclei comprised $2.1 \%$ of total nuclei $(p=0.004$, Fig. 5 b).

Examination of Pax7 expression by RT-PCR showed a similar trend as Pax7 staining. Pax7 mRNA expression increased throughout recovery with 3.2- and 3.5-fold increases at 9 and 14 days post injury being significant $(p=0.02, \quad p=0.015)$. Although the 3-fold changes observed by RT-PCR are smaller than the approximate 6-fold change observed in staining, the trends appear to be consistent, with increased Pax7+ nuclei appearing through the final 10 days of regeneration (Fig. 5d). Myogenin (MyoG) expression was also analysed, as a later myogenic marker than $\mathrm{MyoD}$, it would be expected to follow a similar trend but temporally delayed. The trend of MyoG expression is broadly similar to MyoD-positive nuclei with a rise following 2 days of regeneration and partially resolving at day 9 post injury. An increase at 14 days post injury is observed although this is not statistically significant (Fig. 5d).

The non-myogenic transcription factors Runx2 and Pparg were also examined to illuminate the dynamics of 

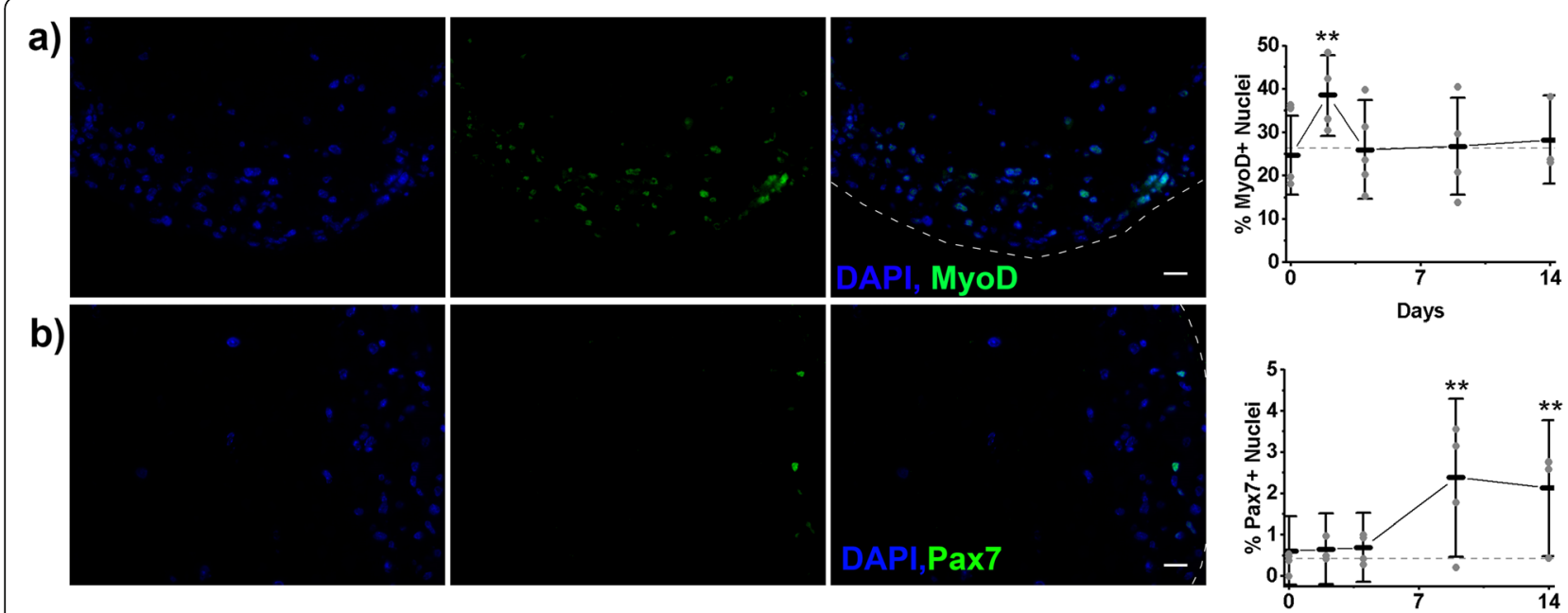

c)

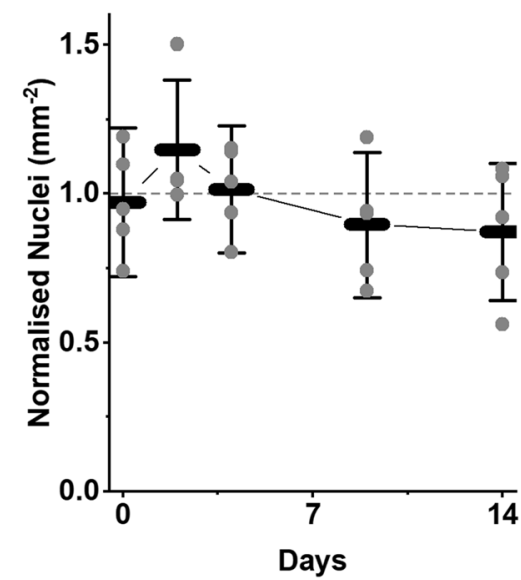

d)

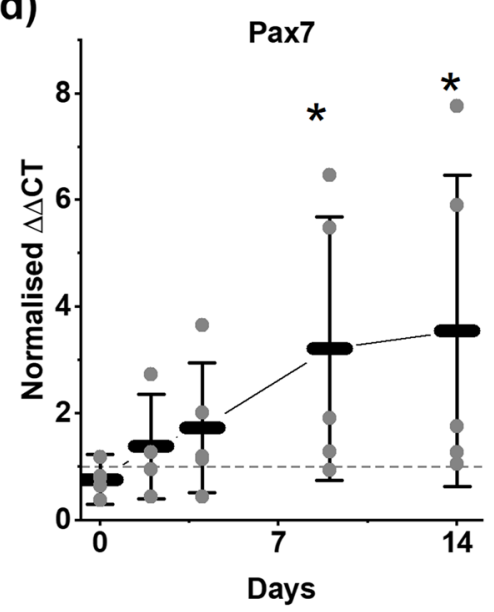

e)

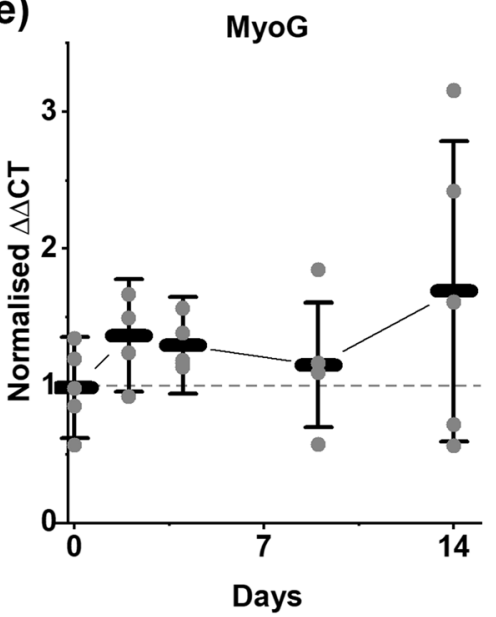

Fig. 5 Dynamics of cell populations following injury. a Representative images showing staining left to right, Nuclei (DAPI, blue), MyoD (green) and overlay image. Scale bar represents $25 \mu \mathrm{m}$. Graph displays percentage of MyoD+ nuclei across recovery. b Representative images showing staining left to right, Nuclei (DAPI, blue), Pax7 (green) and overlay image. Scale bar represents $25 \mu \mathrm{m}$. Graph displays percentage of Pax7+ nuclei across recovery. c Normalised nuclei per $\mathrm{mm}^{2}$ across recovery, mean value at control $-1471 \mathrm{~mm}^{-2}$. $\mathbf{d}$ RT-PCR data displayed as $\Delta \Delta C T$ values for myogenic genes Pax7 and MyoG across recovery. a-e All graphs display means \pm S. D, individual repeat means are displayed as points. Dashed line represents level at control on all graphs. Statistical significance from control is denoted as ${ }^{*} p \leq 0.05,{ }^{* *} p \leq 0.01$ and ${ }^{* * *} p \leq 0.001, n=15$ samples across 5 repeats

potentially non-myogenic cells which in vivo can drive the formation of non-regenerative defects such as increased interstitial fat and heterotopic bone. Runx2 mRNA showed no statistically significant deviation from control levels, although an increase was observed at all time points across the first 9 days of regeneration (Additional file 1: Fig. S4). Pparg mRNA was significantly increased throughout regeneration, with the exception of immediately post injury. At 2 and 4 days post injury, Pparg mRNA expression was elevated 1.88- and 1.89fold, respectively $(p<0.001, p<0.001)$. This expression was reduced to 1.37 -fold at 9 days post injury $(p<0.001)$ before elevating again to 2.16-fold ( $p<0.001$, Additional file 1: Fig. S4) after 14 days of regeneration. The upregulation of Pparg suggests a level of non-myogenic repair occurring in response to injury.

\section{Discussion}

Here we have demonstrated, by the exploitation of wellestablished tissue engineering approaches, a protocol which allows the generation of engineered human muscle with the capacity to regenerate function following injury. The tissues generated are functional, contain the mixed cell populations represented in muscle and demonstrate myogenic population dynamics reminiscent of in vivo tissue. Although previous work has shown that engineered muscles can regenerate following injury [4649], no previous work has demonstrated functional 
recovery in human engineered muscles [52]. The injury sustained following $\mathrm{BaCl}_{2}$ treatment is robust, leading to significant loss of myotubes and function. As with in vivo skeletal muscle wound healing and previous primary tissue engineered muscles, injury is followed by a period (in this model 4 days) of impaired function and reduced myotube number $[48,49,51]$. This contrasts with our previous cell line based 3D models, which isolates the response of committed myogenic cells, and shows a very rapid recovery of function with no prolonged post injury period [46]. Following this initial period without myotube formation, a complete recovery of myotube number and function was observed in line with similar injury types in animal models and previous engineered tissues [46, 47, 49,51]. This demonstrates the regenerative capacity of human skeletal muscle ex vivo and positions this model as a useful tool in examining the underlying biology of skeletal muscle regeneration and repair.

Initially, we demonstrate that the remixing of CD56and CD56+ cells is required to create robust engineered muscles in line with our previous work $[45,53]$. Other models have shown that it is possible to generate CD56+ only engineered tissue, but this work utilises a fibrin-based hydrogel and an FGF2 supplemented myogenic growth media and these differences may explain the contrasting requirement for CD56- cells [54]. This protocol demonstrates that only a very low proportion of non-myogenic cells are required to drive hydrogel deformation, allowing a high percentage of myogenic cells to be exploited (Fig. 1). MidiMACS sorting is unlikely to be absolutely efficient in producing a population of homogeneous cells on the basis of CD56 expression; however, the desmin positivity values in excess of $90 \%$ observed here suggest a highly efficient sorting yield. In addition to increasing myogenic potential, sorting and remixing reduces donor to donor variation in desmin positivity, a common observation with hMPCs, reducing some of the donor variability and likely increasing experimental power. Finally, sorting allows separate expansion of myogenic and nonmyogenic populations and therefore extends the usability of hMPCs. hMPCs unsorted rarely retain sufficient desmin positivity for engineered tissue after 6 passages, and therefore a standard microbiopsy sample would yield approximately $100 \times 50 \mu \mathrm{L}$ engineered muscles. However, sorting cells allows further expansion (up to at least 9 passages, which could potentially be extended) and a projected 20-fold increase in MPC yield allowing 2000 engineered muscles to be generated per biopsy sample. Taken together, these advantages suggest clear rational for exploiting CD56 sorting for hMPC tissue engineering and solves one of the key limitations of using hMPCs.
Remixing of separate populations produces a method to increase cell yield and reproducibility of engineered human skeletal muscle by allowing the expansion of competing populations in isolation. A remixing ratio of 10:90 (-ve:+ve) was selected as this ratio allowed the maximum percentage of myogenic cells to be incorporated into a construct which reproducibly remodelled to generate tension between the anchor pins. We did not examine more in-depth markers of remodelling, such as matrix metalloproteases (MMPs) or their tissue inhibitors (TIMPs), which may be of interest in future work to refine this model. In addition to remodelling the matrix, the CD56- fraction contains a range of other cell types found within the muscle (Additional file 1: Fig. S3) which have been shown in vivo to play important roles in muscle regeneration. This remixing is therefore also key to preserving the biological validity and utility of hMPCs. Identified through flow cytometry PDGFR $\alpha+$ cells (FAPs), CD90+ (MSCs), CD45+ cells (immune lineage) and $\mathrm{CD} 31+$ (endothelial cells) were all identified alongside TE7+ cells (interstitial fibroblasts). The sum of the population fractions, although calculated across two methods, approximates at $99 \%$ of the total population suggesting that the predominant lineages within this population are accounted for, although not confirmed beyond surface marker expression. All of these cell types have suggested roles within the regenerative process and their inclusion may underpin some of the regenerative capacity of this model and at the very least provide an opportunity to examine in vitro how these populations behave following muscle insult.

However, even utilising CD56 sorting, without media supplementation engineered muscles of this type have relatively low numbers of myotubes and produce functional output close to the limit of detection reducing the usefulness of this key measure. To further improve the quality of engineered tissues growth factor supplements (FGF2) and commercial supplement cocktails (B-27) were used. B-27 supplement is widely used in primary neuronal and stem cell cultures $[55,56]$. The supplement contains a broad range of components aimed at promoting redox balance, increasing metabolic flexibility, providing trace nutrients and driving cell growth with supplemental growth factors (Insulin) and steroids (triiodothyronine (T3), corticosterone and progesterone). The roles of these components are broad with protection from redox stress and provision of trace nutrients likely to promote cell survival and lead to increased cell numbers [57]. Growth factors and steroid hormones are more likely to have cell type-specific effects, with insulin having been shown in myoblasts to increase fusion and the expression of myogenic genes, as well as driving proliferation [58, 59]. Thyroid hormones have wellestablished roles in regulating skeletal muscle growth 
and differentiation, with hypothyroidism leading to reduced muscle mass [60]. At a molecular level, the action of T3 on the expression of myogenic genes, MyoD and Myogenin, has been clearly established suggesting T3 will drive myogenesis in engineered muscles [61, 62]. The effects of progesterone on skeletal muscle remain relatively unexamined, with the expression of progesterone receptors yet to be confirmed in myoblasts [63]. Finally, corticosterone, which has only a limited role in humans with its ortholog cortisol being the predominant corticosteroid, drives skeletal muscle atrophy and inhibits insulin signalling in vivo and may perform a similar function in culture [64]. The paucity of data makes the action of progesterone, and the apparent adversarial effects of insulin vs corticosterone, makes it difficult to unpick precisely the role of each component in B-27 and future work may be required to better understand the mechanisms by which the supplement drives myogenesis. Previous work using B-27 with skeletal muscle myoblasts has been shown to promote myoblast survival, but not differentiation in primary rat MPCs [65] whilst as a serum replacement for iPSCs B-27 promotes myogenesis [56]. In the first case, B-27 was included throughout culture and may better compare with the addition of B-27 to the growth phase in this work where increases in cell number were observed but no increase in myogenesis. Whereas in the work by Jiwlawat et al., the addition of B-27 occurs to support terminal differentiation, which is similar to the addition of B-27 in the differentiation phase in this work.

The growth factor FGF2 is known to promote myoblast proliferation, matrix remodelling and attachment and is widely used in MPC culture $[45,66]$ whilst also inhibiting differentiation $[67,68]$ and so was only used in the growth phase of engineered muscles. A doubling in force production shows an effect of supplementation, but this is not driven by an increase in nuclei at maturity. It is possible proliferation may happen earlier in FGF2 supplemented muscles or that there is a priming effect of FGF2 which leads to increased maturity and so force production. The data presented here does not allow this to be examined further. Together, this data demonstrates that supplementation effectively improves the quality of engineered muscle (MyHC coverage and force production) produced from hMPCs and although this may not be the absolute optimal supplementation protocol presents a viable solution to produce functional human engineered muscle (Fig. 2).

Although myotube CSA and MyHC coverage are low compared to somatic human muscle [69], morphological examination of engineered tissues reveals an organised basement membrane, shown by laminin rings surrounding muscle fibres and the presence of Pax7-positive nuclei (Fig. 3). However, the niche present in native muscle contains approximately $5-8 \%$ of Pax $7+$ nuclei, substantially greater (10/15-fold) than observed in control engineered tissues [70,71]. This may be explained by a lack of developmental cues such as the exercise/injury seen in vivo which activate satellite cells and cause proliferation [72]. These Pax7+ cells, however rare, are a key feature of skeletal muscle, underpinning the regenerative capacity of in vivo skeletal muscle and supporting tissue growth and turnover, and therefore should be present in models of engineered skeletal muscle [2, 5, 73].

To examine if these engineered tissues follow similar patterns of regeneration as native skeletal muscle, myogenic and non-myogenic markers were examined through protein and mRNA expression. During the initial 2 days following injury, a proliferative response of MyoD+ myoblasts was observed, before a return to preinjury levels, a response consistent with in vivo data. However, no increase in Pax7+ nuclei was observed during this period as would be expected from in vivo data [7]. This lack of Pax7 proliferation could be due to a lack of activation of these cells following injury, with regeneration driven instead by unfused MyoD+ MPCs, or due to the very low percentages of Pax7+ nuclei present making any changes difficult to detect. Distinguishing between these possibilities is difficult. However, the increases in mRNA expression of Pax7 and Pax7+ nuclei later in regeneration suggest a capacity to expand this cell population, increase the proportion of these cells potentially mimicking the self-renewing capacity of satellite cells in vivo $[74,75]$. It cannot however be absolutely confirmed, without an equivalent of a contralateral control, which is not included, that the increased prevalence of Pax7+ nuclei observed could be due to repeated growth and differentiation phases, and not solely driven by the injury response. Indeed, the post injury proportion of Pax7+ nuclei $(2.1 \%)$ is more closely aligned to in vivo proportions (4-7\%) than the pre-injury $(0.4 \%)$, suggesting that an injury stimulus may be required to trigger population expansion. We have however not presented any direct evidence here that the Pax7+ cells present in this model support regeneration directly. To achieve this, lineage tracing experiments with persistent Pax7-dependent markers would be required. Instead, it is possible, as suggested above, that unfused nuclei within the model, often referred to as reserve cells, support regeneration following injury and not the Pax7+ cells. As the fusion index of control engineered muscles is estimated at approx. $40 \%$ there are significant numbers of unfused Pax7- nuclei which could support regeneration. It is not possible to accurately suggest the relative contribution of these two populations without robust tracing experiments. The data presented does show that engineered human tissues can mimic some of the key events of regeneration, including the expansion 
of MPCs and the expansion of the Pax7+ cell population alongside the recovery of function and myotubes making these engineered tissues an attractive model for understanding skeletal muscle regenerative physiology (Figs. 4 and 5).

Non-myogenic markers Pparg and Runx2 drive nonregenerative repair defects in vivo [76, 77]. Pparg showed an upregulation across regeneration, although this was lower in magnitude than non-regenerative expression in vivo [77], and may be due to increased myotube or MPC expression and not indicative of adipogenic differentiation [78]. Runx2 does not show significant upregulation although some variation from control is observed (Additional file 1: Fig. S4). As remixed engineered muscles contain a range of cell types obtained from skeletal muscle, these expression patterns may represent the expansion, or increased activity of non-regenerative cells types, which should allow future work to examine how these populations progress to develop non-regenerative defects and how they may be manipulated to improve clinical outcomes.

Currently, three published models show a regenerative skeletal muscle [47-49, 52]. Of these, two are collagenbased engineered tissues, whilst the third is a fibrinbased system. All systems have examined injury through the application of cardiotoxin (CTX), with one system also utilising a crush injury. The most recent, from Rajabian et al., shows the regeneration of myotubes of human engineered tissues in both a collagen- and fibrinbased system, although does not examine engineered tissue function. The collagen-based system regenerates myotubes following 5 days of regeneration, but no further analysis is presented to compare to the data presented here, although further analysis is undertaken in a fibrin-based model. The remaining collagen-based system, Tiburcy et al., utilises primary rat MPCs and shows a m-cadherin-lined SC niche and has a regenerative capacity similar to the model presented here, with the ability to regenerate force and morphology following an injury which completely ablates the ability of the tissue to regenerate force. In addition, this model shows a comparable response with regards to Pax7+ proliferation, with an increase across time following injury rather than a brief and temporally confined increase in Pax7+ nuclei. This is in contrast with fibrin systems containing both human and rat based MPCs which display a Pax7 proliferative wave and subsequent resolution. Interestingly, with a crush injury as opposed to chemical insult, Tiburcy et al. demonstrate that collagen-based engineered muscles display this peak in Pax7 and resulting resolution rather than in progressively increasing population. Fibrin-based systems appear to have a more limited regenerative capacity in response to significant functional injury. Both this model and that of Tiburcy et al. show complete ablation of force following injury and complete recovery; however, Juhas et al. see a limit of $50 \%$ functional reduction before regeneration no longer occurs, even in the presence of regeneration supporting macrophages. In summary, although this model remains the only model to show the functional regeneration of a human engineered tissue, it broadly shares similar characteristics with other published models. Interestingly, the closest comparison can be made with the collagen/Matrigel ${ }^{\circ}$ based system of Tiburcy et al. which utilises rat MPCs bringing into focus the key role of matrix composition in these engineered tissues.

\section{Conclusions}

The model presented here provides a platform to generate large numbers of tissue engineered muscles from a single microbiopsy. Utilising CD56 sorting and media supplementation this protocol is robust and allows researchers, in combination with the open source mould system, to rapidly generate human skeletal muscle tissues within their laboratory [79]. The demonstration that these tissues regenerate following chemical insult allows the study of human skeletal muscle regeneration, including cell population dynamics across time, to be undertaken without the need to invasively sample patients repeatedly. In addition, the flexibility of the system allows for future work to build complexity, such as through the addition of immune cells to simulate an inflammatory response [48] or mechanical/electrical stimulation to capture the effects of post-injury exercise $[34,44]$. As the complexity and maturity of these models develop, they will present an opportunity to test putative clinical interventions in a high/medium throughput manner on human tissue, adding a novel tool to the preclinical testing tool box to help improve lead screening and ultimately improve healthcare for patients.

\section{Methods \\ Isolation and culture of hMPCs from skeletal muscle biopsies}

Participants were recruited according to Loughborough University ethical and consent guidelines (Ethics no. R18-P098), with anonymised participant characteristics presented in Additional file 1: Table S1. Biopsies were collected by microbiopsy method from the vastus lateralis [80]. All collected tissue was minced finely, and connective tissue removed. Minced tissue was then plated out and cells isolated by explant culture $[43,55]$. Once collected cells were expanded to passage 3 (p3) in gelatin-coated $(0.2 \% \mathrm{v} / \mathrm{v})$ culture flasks. At $\mathrm{p} 3$ cells were sorted for the presence of the myogenic cell surface marker CD56 [81], using a MidiMACS ${ }^{\text {Tn }}$ system (Miltenyi Biotech, DE). Further expansion of the separate populations was then undertaken, CD56+ cells in Corning ${ }^{\circ}$ 
Matrigel $^{\circ}$ basement membrane matrix-coated $(1 \mathrm{mg} / \mathrm{mL}$, Fisher Scientific, UK) flasks and CD56- cells in gelatin solution (Sigma-Aldrich, UK)-coated flasks. At p5 cells were cryopreserved or further expanded and used between p7 and p9. Throughout explant and expansion cells were maintained in growth media (GM - 79\% high glucose Dulbecco's modified Eagle's medium (DMEM, Sigma, UK), 20\% fetal bovine serum (FBS, PanBiotech, $\mathrm{UK})$ and $1 \%$ penicillin/streptomycin (P/S, Fisher, UK)). For the culture of minced tissue, 1\% Amphotericin B (Sigma, UK) was added to standard GM. At no point were flask cultures allowed to exceed $65 \%$ confluence and were split at a ratio of 1:3 at passage.

\section{Generation of tissue engineered muscles}

Engineered muscles were made as described previously $[43,46]$. Briefly, $65 \% \mathrm{v} / \mathrm{v}$ acidified type I rat tail collagen $(2.035 \mathrm{mg} / \mathrm{mL}$, First link, UK) and $10 \% \mathrm{v} / \mathrm{v}$ of $10 \times \mathrm{min}-$ imal essential medium (MEM, Sigma) were mixed and neutralised. This was followed by the addition of $20 \% \mathrm{v} /$ v Matrigel $^{\circ}$ and $5 \% \mathrm{v} / \mathrm{v}$ GM containing hMPCs at a final density of $4 \times 10^{6}$ cells $/ \mathrm{mL}$ and in a ratio of 9:1 CD56+: CD56- unless otherwise stated. The final solution was transferred to pre-sterilised biocompatible polylactic acid (PLA) FDM printed removable box $50 \mu \mathrm{L}$ inserts [82] to set for $10-15 \mathrm{~min}$ at $37^{\circ} \mathrm{C}$. All moulds used in this manuscript are freely available to download at the following URL: https://figshare.com/projects/3D_Printed_ Tissue_Engineering_Scaffolds/36494. Engineered skeletal muscles were maintained in GM with $5 \mathrm{ng} / \mathrm{mL}$ FGF-2 (Peprotech, USA) for 4 days, changed every $48 \mathrm{~h}$. Following 4 days media was changed to differentiation media (DM - 97\% DMEM, 2\% horse serum and 1\% P/S) supplemented with Gibco $^{\text {Tx }}$ B-27 ${ }^{\text {mix }}$ Supplement $(50 \times$, 1:50, Sigma) for a further 10 days.

\section{Barium chloride injury and regeneration}

Once engineered muscles had reached maturity (14 days), as defined above, they were exposed to chemical injury by $\mathrm{BaCl}_{2}$. Prior to inducing injury, fresh $\mathrm{DM}$ was added to all conditions. Precisely $50 \mu \mathrm{L} / \mathrm{mL}$ of $12 \% \mathrm{w} / \mathrm{v}$ $\mathrm{BaCl}_{2}$ solution was then added to the medium for injury culture conditions, followed by a $6 \mathrm{~h}$ incubation to induce injury. Addition of $\mathrm{BaCl}_{2}$ to cell culture media may produce a white precipitate which has the potential to obscure immunohistochemical analysis. For applications not utilising sectioning techniques for imaging, nonphosphate/sulphate buffers can be considered to prevent precipitate formation [83]. Following injury, cultures were washed once with phosphate-buffered saline (PBS) to remove residual $\mathrm{BaCl}_{2}$ containing media. Control (no injury) and $0 \mathrm{~h}(0 \mathrm{~h})$ time points were collected at the end of injury incubation. Additional time points at 2, 4, 9 and 14 days post injury were collected for all measures to examine the regenerative response across time. For the first 4 days of regeneration engineered muscles were maintained in GM with FGF2, and the remaining 10 days DM with B-27.

\section{Tissue fixation, sectioning and staining}

Engineered muscles were fixed in 3.75\% formaldehyde solution overnight at $4{ }^{\circ} \mathrm{C}$ and then stored in PBS. Prior to cryosectioning, engineered muscles were stored in $20 \%$ sucrose solution $\mathrm{w} / \mathrm{v}$ for $24 \mathrm{~h}$ at $4{ }^{\circ} \mathrm{C}$ to reduce water content and then were frozen under isopentane in liquid nitrogen. Sections were then prepared using standard cryotomy methodology. Cross-sections for MyHC staining were prepared at $12 \mu \mathrm{m}$, whilst Pax7 and MyoD staining used $4 \mu \mathrm{m}$ sections. Longitudinal sections were prepared at $10 \mu \mathrm{m}$.

Sections were incubated overnight at $4{ }^{\circ} \mathrm{C}$ with primary antibodies and $1 \mathrm{~h}$ with secondary antibodies (Fisher, Goat anti-mouse/rabbit 488/647, 1:500). For Pax7 (deposited to the DSHB by Kawakami, A., US, 1:125) and MyoD (Santa Cruz Biotechnology, US, sc-377,460, 1: 200), antigen rescue at $75^{\circ} \mathrm{C}$ in citrate buffer ( $\mathrm{pH}$ 6) for 20 min was performed before the addition of primary antibody. For Laminin (Abcam, ab11575,1:200) and MyHC (deposited to the DSHB by Fischman, D.A., MF20, 1:200), antigen rescue was not required. DAPI (Fisher, 1:1000) was used to stain nuclei.

Images were collected on a Leica DM2500 microscope using Leica Application Suite X software. Fiji 1.52e [84] was used for image analysis, and an in house macro performed automated myotube and nuclei analysis. Pax7and MyoD-positive nuclei analysis was performed manually. Five random images per repeat, per measure were taken and analysed to generate the presented data.

\section{RNA extraction and real-time polymerase chain reaction (RT-PCR)}

Engineered muscles were snap frozen upon collection and TRIReagent ${ }^{\circ}$ extraction was augmented by mechanical disruption of constructs in a TissueLyser II (Qiagen, UK) for $5 \mathrm{~min}$ at $20 \mathrm{~Hz}$. Following disruption, RNA extraction was carried out using chloroform extraction, according to the manufacturer's instructions (TRIReagent ${ }^{\circ}$, Sigma). RNA concentration and purity were obtained by UV-Vis spectroscopy (Nanodrop ${ }^{\text {in }}$ 2000, Fisher).

All primers (Additional File 1: Table S2) were validated for $5 \mathrm{ng}$ of RNA per $10 \mu \mathrm{L}$ RT-PCR reaction. RTPCR amplifications were carried out using Power SYBR Green RNA-to-CT 1 step kit (Qiagen, UK) on a 384 well ViiA Real-Time PCR System (Applied Bio-systems, Life Technologies, ThermoFisher, USA) and analysed using ViiA 7RUO Software. RT-PCR procedure was $50^{\circ} \mathrm{C}, 10$ min (for cDNA synthesis); $95^{\circ} \mathrm{C}, 5 \mathrm{~min}$ (reverse transcriptase inactivation); and followed by 40 cycles of 
$95^{\circ} \mathrm{C}, 10 \mathrm{~s}$ (denaturation); $60{ }^{\circ} \mathrm{C}, 30 \mathrm{~s}$ (annealing/extension). Melt analysis was then carried out using standard ViiA protocol. Relative gene expressions were calculated using the comparative CT $(\Delta \Delta \mathrm{CT})$ method giving normalised expression ratios [85]. RPII $\beta$ was the designated housekeeping gene in all RT-PCR assays and sample controls for each primer set were included on every plate.

\section{Measurement of engineered muscle function}

Electric field stimulation was used in order to assess the functional capacity (force generation) of tissue engineered constructs. Constructs were washed twice in PBS, and one end of the construct removed from the supporting mould pin. The free end of the construct was then attached to the force transducer (403A Aurora force transducer, Aurora Scientific, CA) using the eyelet present in the construct. The construct was positioned to ensure its length was equal to that before removal from the pin and covered $(3 \mathrm{~mL})$ with Krebs-RingerHEPES buffer solution (KRH; $10 \mathrm{mM}$ HEPES, $138 \mathrm{mM}$ $\mathrm{NaCl}, 4.7 \mathrm{mM} \mathrm{KCl}, 1.25 \mathrm{mM} \mathrm{CaCl}, 1.25 \mathrm{mM} \mathrm{MgSO}_{4}, 5$ $\mathrm{mM}$ glucose, $0.05 \%$ bovine serum albumin in $\mathrm{dH}_{2} \mathrm{O}$, Sigma, UK). Aluminium wire electrodes, separated by $10 \mathrm{~mm}$, were positioned parallel either side of the construct to allow for electric field stimulation. Impulses were generated using LabVIEW software (National Instruments, UK) connected to a custom-built amplifier. Maximal twitch force was determined using a single 3.6 $\mathrm{V} / \mathrm{mm}, 1 \mathrm{~ms}$ impulse and maximal tetanic force was measured using a $1 \mathrm{~s}$ pulse train at $100 \mathrm{~Hz}$ at $3.6 \mathrm{~V} / \mathrm{mm}$, generated using LabVIEW 2012 software (National Instruments). Twitch and tetanus data were derived from 3 contractions per construct, and a minimum of 2 constructs per time point per biological repeat. Data was acquired using a Powerlab system (ver. 8/35) and associated software (Labchart 8, AD Instruments, UK). Force is presented as both absolute force $(\mu \mathrm{N})$ and specific force relative to construct cross-sectional area $(\mathrm{kPa})$ for comparison. Specific force was calculated using average absolute force values normalised with average associated cryosection CSA.

\section{Flow cytometry}

CD56- cells were resuscitated from liquid nitrogen, at $\mathrm{P} 6$, and incubated in $\mathrm{GM}$ for $30 \mathrm{~min}$ at $37^{\circ} \mathrm{C}, 5 \% \mathrm{CO}_{2}$. Cells were then filtered using MACS pre-separation filters to remove potential cell clumps. Cells were then washed once in fluorescence associated cell sorting buffer (FACS; 1\% BSA, $0.2 \mathrm{mM}$ EDTA and $0.1 \%$ sodium azide in PBS) and resuspended in $200 \mu \mathrm{L}$ FACS buffer, containing the appropriate antibodies (BD bioscience; PDGFR $\alpha$, 556002, 1:10; CD90, 555595, 1:100; CD45, 555485, 1:10; CD31, 746116: 1:100), at a concentration of $1 \times 10^{6}$ cells $/ \mathrm{mL}$ and incubated for $30 \mathrm{~min}$ on ice. Cells were then washed with FACS and resuspended at $0.5 \times 10^{6}$ cells $/ \mathrm{mL}$. Flow data acquisition was then undertaken using a BD Accuri C6 flow cytometer, at fast flow rate. To ensure accurate gating of positive populations, fluorescence minus one (FMO) controls were used to set gates. Due to the low percentages of positive cells fluorescence compensation was carried out using antibody binding compensation beads (BD, 552843). Analysis of flow data was undertaken in BD C6 software and representative gating patterns are shown in Additional file 1: Fig. S2.

\section{Experimental repeats}

For all injury experiments (Figs. 4 and 5), 5 repeats across 3 donors were performed with each repeat yielding a minimum of 3 engineered muscles per analysis type, values from each individual engineered muscle were used for statistical analysis. For cell composition and media supplementation (Figs. 1 and 2), 2 repeats across 2 donors were performed with 3 engineered muscles per analysis technique. A total of 5 donors were used for the entirety of the experimental work.

\section{Statistical analysis}

Statistical analysis was undertaken in IBM SPSS 23. Data was subjected to tests of normality (Shapiro-Wilk) and homogeneity of variance (Levene's test). Where parametric assumptions were met, an ANOVA test was used to identify significant interactions. Where significant interactions were observed, Bonferroni post hoc analyses were used to analyse differences between specific timepoints or groups. Non-parametric Kruskal-Wallis analysis was undertaken where data violated parametric assumptions. Mann-Whitney $(U)$ tests were then used, with a Bonferonni correction, to identify the differences between groups. Comparisons across time were made between control and the time point of interested and quoted $p$ values refer to this comparison. All data are reported as mean \pm standard deviation (SD). Significance was assumed at $p \leq 0.05$ and denoted on graphs with asterisks at indicated levels of significance. Without exception, an asterisk above a bar or point indicates that the mean of the indicated condition deviates significantly from the associated control.

\section{Supplementary information}

Supplementary information accompanies this paper at https://doi.org/10. 1186/s12915-020-00884-3.

Additional file 1: Table S1. Individual donor characteristics. Table S2. Primer sequence table. Figure S1. CD56 enrichment improves desmin positivity and morphological appearance of tissue engineered constructs. Figure S2. Characterisation of CD56- populations. Table S3. Table of donor sorting efficiencies and yields. Figure S3. Col IV and Laminin 
localisation in engineered skeletal muscles. Figure S4. Expression of Runx2 and Pparg across recovery.

\section{Abbreviations}

GM: Growth medium; DM: Differentiation medium; ECM: Extracellular matrix; MPC: Myogenic precursor cell; hMPC: Human myogenic precursor cell; MyHC: Myosin heavy chain; SC: Satellite cell; VML: Volumetric muscle loss; FAP: Fibro/adipogenic cell; 3D: Three dimensional; PSC: Pluripotent stem cell; DMEM: Dulbecco's modified Eagle's medium; FBS: Fetal bovine serum; P/ S: Penicillin/Streptomycin; MEM: Minimal essential medium; PBS: Phosphate buffered saline; KRH: Krebs-Ringer-HEPES; $\mathrm{BaCl}_{2}$ : Barium chloride

\section{Acknowledgements}

Not applicable.

\section{Authors' contributions}

J.F. contributed to the design of experiments, performed all experimental work and data analysis and drafted the manuscript. A.C., R.R. and O.D. contributed significantly to experimental design and critically reviewed the manuscript throughout the drafting process. P.W. critically reviewed the manuscript and conducted all biopsies for this study. N.B. and A.L. designed, optimised and collected all flow cytometry data and directed analysis thereafter, both critically reviewed the manuscript. M.L. conceived the concept of the work, contributed to experimental design and critically reviewed the manuscript. All authors read and approved the final manuscript.

\section{Funding}

The authors would like to acknowledge Loughborough University and EPSRC (grant reference EP/N509516/1) for funding and support for this work.

\section{Availability of data and materials}

All data generated or analysed during this study are included in this published article and its supplementary information files.

\section{Ethics approval and consent to participate}

Participants were recruited according to Loughborough University ethical and consent guidelines (Ethics no. R18-P098).

\section{Consent for publication}

\section{Competing interests}

The authors declare that they have no competing interests.

Received: 7 May 2020 Accepted: 30 September 2020

Published online: 20 October 2020

\section{References}

1. Järvinen $T A$, Järvinen $M$, Kalimo $H$. Regeneration of injured skeletal muscle after the injury. Muscles Ligaments Tendons J. 2013;3:337-45.

2. Mauro A. Satellite cell of skeletal muscle fibers. J Biophys Biochem Cytol. 1961;:4:493-5.

3. Lepper C, Partridge TA, Fan CM. An absolute requirement for pax7-positive satellite cells in acute injury-induced skeletal muscle regeneration. Development. 2011:138:3639-46.

4. Hindi SM, Kumar A. TRAF6 regulates satellite stem cell self-renewal and function during regenerative myogenesis. J Clin Invest. 2016:126:151-68.

5. Seale P, Sabourin LA, Girgis-Gabardo A, Mansouri A, Gruss P, Rudnicki MA. Pax7 is required for the specification of myogenic satellite cells. Cell. 2000; 102:777-86.

6. Dumont NA, Wang YX, Rudnicki MA. Intrinsic and extrinsic mechanisms regulating satellite cell function. Development. 2015;142:1572-81.

7. Tian ZL, Jiang SK, Zhang M, Wang M, Li JY, Zhao R, et al. Detection of satellite cells during skeletal muscle wound healing in rats: time-dependent expressions of Pax7 and MyoD in relation to wound age. Int J Legal Med. 2016:130:163-72

8. Zammit PS. Function of the myogenic regulatory factors Myf5, MyoD, Myogenin and MRF4 in skeletal muscle, satellite cells and regenerative myogenesis. Semin Cell Dev Biol. 2017;72:19-32.
9. Bi P, Ramirez-Martinez A, Li H, Cannavino J, McAnally JR, Shelton JM, et al. Control of muscle formation by the fusogenic micropeptide myomixer. Science (80- ). 2017;356:323-7.

10. Quinn ME, Goh Q, Kurosaka M, Gamage DG, Petrany MJ, Prasad V, et al. Myomerger induces fusion of non-fusogenic cells and is required for skeletal muscle development. Nat Commun. 2017:8:1-9.

11. Millay DP, O'Rourke JR, Sutherland LB, Bezprozvannaya S, Shelton JM, BasselDuby $\mathrm{R}$, et al. Myomaker is a membrane activator of myoblast fusion and muscle formation. Nature. 2013:499:301-5.

12. Joe AW, Yi L, Natarajan A, Le Grand F, So L, Wang J, et al. Muscle injury activates resident fibro/adipogenic progenitors that facilitate myogenesis. Nat Cell Biol. 2010;12:153-63.

13. Uezumi A, Fukada S, Yamamoto N, Takeda S, Tsuchida K. Mesenchymal progenitors distinct from satellite cells contribute to ectopic fat cell formation in skeletal muscle. Nat Cell Biol. 2010:12:143-52.

14. Merly F, Lescaudron L, Rouaud T, Crossin F, Gardahaut MF. Macrophages enhance muscle satellite cell proliferation and delay their differentiation. Muscle Nerve. 1999;22:724-32.

15. Summan M, Warren GL, Mercer RR, Chapman R, Hulderman T, Van Rooijen $\mathrm{N}$, et al. Macrophages and skeletal muscle regeneration: a clodronatecontaining liposome depletion study. Am J Physiol Regul Integr Comp Physiol. 2006;290:R1488-95.

16. Segawa M, Fukada Sichiro, Yamamoto Y, Yahagi H, Kanematsu M, Sato M, et al. Suppression of macrophage functions impairs skeletal muscle regeneration with severe fibrosis. Exp Cell Res 2008;314:3232-3244.

17. Wosczyna MN, Konishi CT, Perez Carbajal EE, Wang TT, Walsh RA, Gan $\mathrm{Q}$, et al. Mesenchymal stromal cells are required for regeneration and homeostatic maintenance of skeletal muscle. Cell Rep. 2019;27:20292035.e5.

18. Mann CJ, Perdiguero E, Kharraz Y, Aguilar S, Pessina P, Serrano AL, et al. Aberrant repair and fibrosis development in skeletal muscle. Skelet Muscle. 2011;1:21

19. Olson LE, Soriano P. Increased PDGFRalpha activation disrupts connective tissue development and drives systemic fibrosis. Dev Cell. 2009:16:303-13.

20. Mueller AA, Van Velthoven CT, Fukumoto KD, Cheung TH, Rando TA. Intronic polyadenylation of PDGFRa in resident stem cells attenuates muscle fibrosis. Nat Publ Gr. 2016;540:276-9.

21. Fournier-Farley C, Lamontagne M, Gendron P, Gagnon DH. Determinants of return to play after the nonoperative management of hamstring injuries in athletes. Am J Sports Med. 2016:44:2166-72.

22. Rose PE. Pathology of Skeletal Muscle, 2nd ed: Carpenter S, Karpati G. ( $£ 140$. 00.) Oxford University Press, 2001. ISBN 019506364 3. Journal of Clinical Pathology. 2002;55:480.

23. Uezumi A, Ito T, Morikawa D, Shimizu N, Yoneda T, Segawa M, et al. Fibrosis and adipogenesis originate from a common mesenchymal progenitor in skeletal muscle. J Cell Sci. 2011;124(Pt 21):3654-64.

24. Belmont PJ, McCriskin BJ, Sieg RN, Burks R, Schoenfeld AJ. Combat wounds in Iraq and Afghanistan from 2005 to 2009. J Trauma Acute Care Surg. 2012; 73:3-12.

25. Wheatley BM, Hanley MG, Wong WW, Sabino JM, Potter BK, Tintle SM, et al. Heterotopic ossification following tissue transfer for combat-casualty complex periarticular injuries. Plast Reconstr Surg. 2015;136:808e-14e.

26. Wangensteen A, Tol JL, Witvrouw E, Van Linschoten R, Almusa E, Hamilton $B$, et al. Hamstring reinjuries occur at the same location and early after return to sport. Am J Sports Med. 2016:44:2112-21.

27. Dharm-Datta S, McLenaghan J. Medical lessons learnt from the US and Canadian experience of treating combat casualties from Afghanistan and Iraq. J R Army Med Corps. 2013;159:102-9.

28. Freckleton G, Pizzari T. Risk factors for hamstring muscle strain injury in sport: a systematic review and meta-analysis. Br J Sports Med. 2013;47:351-8.

29. Fiore D, Judson RN, Low M, Lee S, Zhang E, Hopkins C, et al. Pharmacological blockage of fibro / adipogenic progenitor expansion and suppression of regenerative fibrogenesis is associated with impaired skeletal muscle regeneration. Stem Cell Res. 2016;17:161-9.

30. Lemos DR, Babaeijandaghi F, Low M, Chang C-K, Lee ST, Fiore D, et al. Nilotinib reduces muscle fibrosis in chronic muscle injury by promoting TNF-mediated apoptosis of fibro/adipogenic progenitors. Nat Med. 2015;21: $786-94$.

31. Agarwal S, Cholok D, Loder S, Li J, Breuler C, Chung MT, et al. mTOR inhibition and BMP signaling act synergistically to reduce muscle fibrosis and improve myofiber regeneration. JCl Insight. 2016;1:1-12. 
32. EU. Directive 2010/63/EU of the European Parliament and of the Council of 22 September 2010 on the protection of animals used for scientific purposes. Off J Eur Union. 2010;L 276:20.

33. Russell WMS, Burch RL, Hume CW. The principles of humane experimental technique; 1959.

34. Aguilar-Agon KW, Capel AJ, Martin NRW, Player DJ, Lewis MP. Mechanical loading stimulates hypertrophy in tissue-engineered skeletal muscle: molecular and phenotypic responses. J Cell Physiol. 2019;234:23547-58.

35. Agrawal G, Aung A, Varghese S. Skeletal muscle-on-a-chip: an in vitro model to evaluate tissue formation and injury. Lab Chip. 2017;17:3447-61.

36. Morimoto $Y$, Onoe H, Takeuchi S. Biohybrid robot powered by an antagonistic pair of skeletal muscle tissues. Sci Robot. 2018;3:eaat4440.

37. Huang Y-C, Dennis RG, Larkin L, Baar K. Rapid formation of functional muscle in vitro using fibrin gels. J Appl Physiol. 2005;98:706-13.

38. Vandenburgh $\mathrm{HH}$, Karlisch $\mathrm{P}$, Farr L. Maintenance of highly contractile tissue-cultured avian skeletal myotubes in collagen gel. In Vitro Cell Dev Biol. 1988;24:166-74.

39. Xu B, Zhang M, Perlingeiro RCR, Shen W. Skeletal muscle constructs engineered from human embryonic stem cell derived myogenic progenitors exhibit enhanced contractile forces when differentiated in a medium containing EGM-2 supplements. Adv Biosyst. 2019:1900005:1-11.

40. Maffioletti SM, Sarcar S, Henderson ABH, Mannhardt I, Pinton L, Moyle LA, et al. Three-dimensional human iPSC-derived artificial skeletal muscles model muscular dystrophies and enable multilineage tissue engineering. Cell Rep. 2018;23:899-908.

41. Rao L, Qian Y, Khodabukus A, Ribar T, Bursac N. Engineering human pluripotent stem cells into a functional skeletal muscle tissue. Nat Commun. 2018;9:1-12.

42. Madden $L$, Juhas M, Kraus WE, Truskey GA, Bursac N. Bioengineered human myobundles mimic clinical responses of skeletal muscle to drugs. Elife. 2015;4:e04885

43. Capel AJ, Rimington RP, Fleming JW, Player DJ, Baker LA, Turner MC, et al. Scalable 3D printed molds for human tissue engineered skeletal muscle. Front Bioeng Biotechnol. 2019;7:20.

44. Khodabukus A, Madden L, Prabhu NK, Koves TR, Jackman CP, Muoio DM, et al. Electrical stimulation increases hypertrophy and metabolic flux in tissue-engineered human skeletal muscle. Biomaterials. 2018;2019(198):25969.

45. Bakooshli MA, Lippmann ES, Mulcahy B, lyer N, Nguyen CT, Tung K, et al. A $3 \mathrm{~d}$ culture model of innervated human skeletal muscle enables studies of the adult neuromuscular junction. Elife. 2019;8:1-29.

46. Fleming JW, Capel AJ, Rimington RP, Player DJ, Stolzing A, Lewis MP. Functional regeneration of tissue engineered skeletal muscle in vitro is dependent on the inclusion of basement membrane proteins. Cytoskeleton. 2019;76:371-82.

47. Juhas M, Engelmayr GCJ, Fontanella AN, Palmer GM, Bursac N. Biomimetic engineered muscle with capacity for vascular integration and functional maturation in vivo. Proc Natl Acad Sci U S A. 2014;111:5508-13.

48. Juhas M, Abutaleb N, Wang JT, Ye J, Shaikh Z, Sriworarat C, et al. Incorporation of macrophages into engineered skeletal muscle enables enhanced muscle regeneration. Nat Biomed Eng. 2018;2:942-54.

49. Tiburcy M, Markov A, Kraemer LK, Christalla P, Rave-Fraenk M, Fischer HJ, et al. Regeneration competent satellite cell niches in rat engineered skeletal muscle. FASEB BioAdvances. 2019;1:731-46.

50. Juhas M, Abutaleb N, Wang JT, Ye J, Shaikh Z, Sriworarat $C$, et al. Incorporation of macrophages into engineered skeletal muscle enables enhanced muscle regeneration. Nat Biomed Eng. 2018;2:942-54.

51. Hardy D, Besnard A, Latil M, Jouvion G, Briand D, Thépenier C, et al. Comparative study of injury models for studying muscle regeneration in mice. PLoS One. 2016;11:e0147198.

52. Rajabian N, Asmani M, Shahini A, Vydiam K, Choudhury D, Nguyen T, et al. Bioengineered skeletal muscle as a model of muscle aging and regeneration. Tissue Eng Part A. 2020; ahead of print.

53. Brady MA, Lewis MP, Mudera V. Synergy between myogenic and nonmyogenic cells in a 3D tissue-engineered craniofacial skeletal muscle construct. J Tissue Eng Regen Med. 2008;2:408-17.

54. Afshar ME, Abraha HY, Bakooshli MA, Davoudi S, Zandstra PW, Gilbert PM. A 96-well culture platform enables longitudinal analyses of engineered human skeletal muscle microtissue strength. Sci Rep. 2020;10:1-16.

55. Martin NRW, Passey SL, Player DJ, Mudera V, Baar K, Greensmith L, et al. Neuromuscular junction formation in tissue-engineered skeletal muscle augments contractile function and improves cytoskeletal organization. Tissue Eng Part A. 2015;21:2595-604.

56. Jiwlawat S, Lynch E, Glaser J, Smit-Oistad I, Jeffrey J, Van Dyke JM, et al. Differentiation and sarcomere formation in skeletal myocytes directly prepared from human induced pluripotent stem cells using a sphere-based culture. Differentiation. 2017:96:70-81.

57. Shaban S, El-Husseny MWA, Abushouk Al, Salem AMA, Mamdouh M, AbdelDaim MM. Effects of antioxidant supplements on the survival and differentiation of stem cells. Oxidative Med Cell Longev. 2017, Article ID 5032102, 16 pages..

58. Saini A, Rullman E, Lilja M, Mandić M, Melin M, Olsson K, et al. Asymmetric cellular responses in primary human myoblasts using sera of different origin and specification. PLoS One. 2018;13:1-16.

59. Wu YJ, Fang YH, Chi HC, Chang LC, Chung SY, Huang WC, et al. Insulin and $\mathrm{LiCl}$ synergistically rescue myogenic differentiation of FoxO1 over-expressed myoblasts. PLoS One. 2014;9, e88450.

60. Bloise FF, Cordeiro A, Ortiga-Carvalho TM. Role of thyroid hormone in skeletal muscle physiology. J Endocrinol. 2018;236:R57-68.

61. Muscat GEO, Mynett-johnson L, Dowhan D, Downes M, Griggs R. Activation of myoD gene transcription by 3,5,3'-triiodo-L-thyronine: a direct role for the thyroid hormone and retinoid X receptors. Nucleic Acids Res. 1994;22: 583-91.

62. Downes M, Griggs R, Atkins A, Olson EN, Muscat GEO. Identification of a thyroid hormone response element in the mouse myogenin gene: characterization of the thyroid hormone and retinoid $\mathrm{X}$ receptor heterodimeric binding site. Cell Growth Differ. 1993:4:901-10.

63. Kim YJ, Tamadon A, Park HT, Kim H, Ku S-Y. The role of sex steroid hormones in the pathophysiology and treatment of sarcopenia. Osteoporos Sarcopenia. 2016;2:140-55.

64. Braun TP, Marks DL. The regulation of muscle mass by endogenous glucocorticoids. Front Physiol. 2015;6:1-12.

65. Das M, Rumsey JW, Bhargava N, Gregory C, Riedel L, Kang JF, et al. Developing a novel serum-free cell culture model of skeletal muscle differentiation by systematically studying the role of different growth factors in myotube formation. In Vitro Cell Dev Biol Anim. 2009;45:378-87.

66. Yablonka-Reuveni Z, Rivera AJ. Temporal expression of regulatory and structural muscle proteins during myogenesis of satellite cells on isolated adult rat fibers. Dev Biol. 1994;164:588-603.

67. Clegg CH, Linkhart TA, Olwin BB, Hauschka SD. Growth factor control of skeletal muscle differentiation: commitment to terminal differentiation occurs in G1 phase and is repressed by fibroblast growth factor. J Cell Biol. 1987;105:949-56.

68. Allen RE, Dodson MV, Luiten LS. Regulation of skeletal muscle satellite cell proliferation by bovine pituitary fibroblast growth factor. Exp Cell Res. 1984; 152:154-60.

69. Lexell J, Taylor CC. Variability in muscle fibre areas in whole human quadriceps muscle: effects of increasing age. J Anat. 1991;174:239-49.

70. Snow MH. Satellite cell distribution within the soleus muscle of the adult mouse. Anat Rec. 1981;201:463-9.

71. Lindström M, Tjust AE, Domellöf FP. Pax7-positive cells/satellite cells in human extraocular muscles. Investig Ophthalmol Vis Sci. 2015;56:6132-43.

72. Macaluso F, Brooks NE, Niesler CU, Myburgh KH. Satellite cell pool expansion is affected by skeletal muscle characteristics. Muscle Nerve. 2013; 48:109-16.

73. Moss FP, Leblond CP. Satellite cells as the source of nuclei in muscles of growing rats. Anat Rec. 1971;170:421-35.

74. Kuang S, Kuroda K, Le Grand F, Rudnicki MA. Asymmetric self-renewal and commitment of satellite stem cells in muscle. Cell. 2007;129:999-1010.

75. Kuang S, Gillespie MA, Rudnicki MA. Niche regulation of muscle satellite cell self-renewal and differentiation. Cell Stem Cell. 2008;2:22-31.

76. Lin L, Shen Q, Leng H, Duan X, Fu X, Yu C. Synergistic inhibition of endochondral bone formation by silencing Hif1a and Runx2 in traumainduced heterotopic ossification. Mol Ther. 2011;19:1426-32.

77. Dammone G, Karaz S, Lukjanenko L, Winkler C, Sizzano F, Jacot G, et al. PPARy controls ectopic adipogenesis and cross-talks with myogenesis during skeletal muscle regeneration. Int J Mol Sci. 2018;19:1-17.

78. Singh J, Verma NK, Kansagra SM, Kate BN, Dey CS. Altered PPARy expression inhibits myogenic differentiation in C2C12 skeletal muscle cells. Mol Cell Biochem. 2007;294:163-71.

79. Rimington R, Capel AJ, Fleming J, Player D, Mudera V, Jones J, et al. 50uL FDM removable insert. 2018; https://doi.org/10.17028/rd.lboro.6969707.v1. 
80. Hayot M, Michaud A, Koechlin C, Caron MA, LeBlanc P, Préfaut C, et al. Skeletal muscle microbiopsy: a validation study of a minimally invasive technique. Eur Respir J. 2005;25:431-40.

81. Illa I, Leon-Monzon M, Dalakas MC. Regenerating and denervated human muscle fibers and satellite cells express neural cell adhesion molecule recognized by monoclonal antibodies to natural killer cells. Ann Neurol. 1992;31:46-52

82. Rimington RP, Capel AJ, Christie SDR, Lewis MP. Biocompatible 3D printed polymers: via fused deposition modelling direct C2C12 cellular phenotype in vitro. Lab Chip. 2017;17:2982-93.

83. Morton AB, Norton CE, Jacobsen NL, Fernando CA, Cornelison DDW, Segal SS. Barium chloride injures myofibers through calcium-induced proteolysis with fragmentation of motor nerves and microvessels. Skelet Muscle. 2019;9: $1-10$.

84. Schindelin J, Arganda-Carreras I, Frise E, Kaynig V, Longair M, Pietzsch T, et al. Fiji: an open-source platform for biological-image analysis. Nat Meth. 2012;9:676-82

85. Schmittgen TD, Livak KJ. Analyzing real-time PCR data by the comparative CT method. Nat Protoc. 2008:3:1101-8.

\section{Publisher's Note}

Springer Nature remains neutral with regard to jurisdictional claims in published maps and institutional affiliations.

Ready to submit your research? Choose BMC and benefit from:

- fast, convenient online submission

- thorough peer review by experienced researchers in your field

- rapid publication on acceptance

- support for research data, including large and complex data types

- gold Open Access which fosters wider collaboration and increased citations

- maximum visibility for your research: over $100 \mathrm{M}$ website views per year

At $\mathrm{BMC}$, research is always in progress.

Learn more biomedcentral.com/submissions 